\title{
GABA: A Key Player in Drought Stress Resistance in Plants
}

\author{
Md. Mahadi Hasan ${ }^{1}$ (D), Nadiyah M. Alabdallah ${ }^{2}$, Basmah M. Alharbi ${ }^{3} \mathbb{D}$, Muhammad Waseem $^{1}$, Guangqian Yao ${ }^{1}$, \\ Xu-Dong Liu ${ }^{1}$, Hany G. Abd El-Gawad ${ }^{4}\left(\mathbb{D}\right.$, Ahmed Abou El-Yazied ${ }^{4}\left(\mathbb{D}\right.$, Mohamed F. M. Ibrahim ${ }^{5}$ (D), \\ Mohammad Shah Jahan ${ }^{6,7}$ and Xiang-Wen Fang ${ }^{1, *}$
}

1 State Key Laboratory of Grassland Agro-Ecosystems, School of Life Sciences, Lanzhou University, Lanzhou 730000, China; hasanmahadikau@gmail.com (M.M.H.); waseem17@lzu.edu.cn (M.W.); yaogq@lzu.edu.cn (G.Y.); liuxd19@lzu.edu.cn (X.-D.L.)

2 Department of Biology, College of Science, Imam Abdulrahman Bin Faisal University, P.O. Box 1982, Dammam 31441, Saudi Arabia; nmalabdallah@iau.edu.sa

3 Biology Department, Faculty of Science, University of Tabuk, Tabuk 71491, Saudi Arabia; b.alharbi@ut.edu.sa

4 Department of Horticulture, Faculty of Agriculture, Ain Shams University, Cairo 11566, Egypt; hany_gamal2005@agr.asu.edu.eg (H.G.A.E.-G.); ahmed_abdelhafez2@agr.asu.edu.eg (A.A.E.-Y.)

5 Department of Agricultural Botany, Faculty of Agriculture, Ain Shams University, Cairo 11566, Egypt; ibrahim_mfm@agr.asu.edu.eg

6 Key Laboratory of Southern Vegetable Crop Genetic Improvement in Ministry of Agriculture, College of Horticulture, Nanjing Agricultural University, Nanjing 210095, China; shahjahansau@gmail.com

7 Department of Horticulture, Sher-e-Bangla Agricultural University, Dhaka 1207, Bangladesh

check for

updates

Citation: Hasan, M.M.; Alabdallah, N.M.; Alharbi, B.M.; Waseem, M.; Yao, G.; Liu, X.-D.; Abd El-Gawad, H.G.; El-Yazied, A.A.; Ibrahim, M.F.M.; Jahan, M.S.; et al. GABA: A Key Player in Drought Stress Resistance in Plants. Int. J. Mol. Sci. 2021, 22, 10136. https: / / doi.org/10.3390/ijms 221810136

Academic Editors: Tomasz Hura, Katarzyna Hura and Agnieszka Ostrowska

Received: 27 August 2021

Accepted: 16 September 2021

Published: 20 September 2021

Publisher's Note: MDPI stays neutral with regard to jurisdictional claims in published maps and institutional affiliations.

Copyright: (C) 2021 by the authors Licensee MDPI, Basel, Switzerland. This article is an open access article distributed under the terms and conditions of the Creative Commons Attribution (CC BY) license (https:/ / creativecommons.org/licenses/by/ $4.0 /)$.
* Correspondence: fangxw@lzu.edu.cn

Abstract: $\gamma$-aminobutyric acid (GABA) is a non-protein amino acid involved in various physiological processes; it aids in the protection of plants against abiotic stresses, such as drought, heavy metals, and salinity. GABA tends to have a protective effect against drought stress in plants by increasing osmolytes and leaf turgor and reducing oxidative damage via antioxidant regulation. Guard cell GABA production is essential, as it may provide the benefits of reducing stomatal opening and transpiration and controlling the release of tonoplast-localized anion transporter, thus resulting in increased water-use efficiency and drought tolerance. We summarized a number of scientific reports on the role and mechanism of GABA-induced drought tolerance in plants. We also discussed existing insights regarding GABA's metabolic and signaling functions used to increase plant tolerance to drought stress.

Keywords: antioxidant enzymes; $\gamma$-aminobutyric acid; proline; stomata; signaling molecule

\section{Introduction}

GABA was discovered in potato tubers and is found in the majority of prokaryotic and eukaryotic species [1]. It is an important component of primary and secondary metabolite synthesis since it is an integral intermediate in nitrogen metabolism and amino acid biosynthesis [2]. In plant growth and development, it functions as an intrinsic signaling molecule. GABA accumulates quickly in plant tissues in response to a variety of abiotic stresses [3].

Drought is a major global challenge in agriculture because the stress it causes disrupts key physiological processes in plants [4,5]. There is a long history of drought responses in plants, with yield reductions are much greater than 25\% [6]. Due to long-term drought, plants also suffer from a decrease in relative water content and various metabolic and photosynthetic abnormalities [7-9]. However, GABA can help plants withstand a variety of environmental stresses, including drought, salt, and heavy metals. Exogenous GABA application can increase the activity of antioxidant enzymes and the glyoxalase system and is involved in MG detoxification [10].

Regulation of the stomatal pore aperture is a major factor in determining plant productivity and drought tolerance [11-15]. GABA-induced stomatal control has gained particular 
attention in recent years. Since GABA acts as a signaling molecule in plants, its role in stomatal movement during drought conditions could be important. To the best of our knowledge, GABA-induced stomatal control has not been extensively reviewed in the literature. Therefore, we intend to address recent advances in GABA-induced stomatal behavior and the underlying mechanisms in plants under drought stress. Additionally, we review the existing literature on the biosynthesis, metabolism, and molecular interactions of GABA in plants in response to drought stress. The aim of this review is to explain the mechanisms involved in GABA-mediated enhancement of plant tolerance in droughtstressed plants through antioxidant activity and synergy with other molecules. We then raise questions to be addressed in future research.

\section{GABA Biosynthesis and Metabolism in Plants}

GABA is produced by a metabolic pathway known as the GABA shunt pathway, which was first observed in plants [1]. GABA shunts are essential for both GABA production and the maintenance of optimal GABA levels. It consists of three major reactions that are catalyzed by the cytosolic enzyme glutamate decarboxylase (GAD, E.C.4.1.1.15), SSADH (succinic semialdehyde dehydrogenase) (E.C.1.2.2.16), and mitochondrial enzymes GABA transaminase (E.C.2.6.1.19).

In a nonreversible reaction, which limits the GABA synthesis rate, glutamic acid decarboxylase (GAD) mainly catalyzes the a-decarboxylation of glutamate to GABA [16]. GABA is transformed to succinic semialdehyde (SSA) by GABA-T, which is then transformed to succinate by SSADH [17], as described in Figure 1.

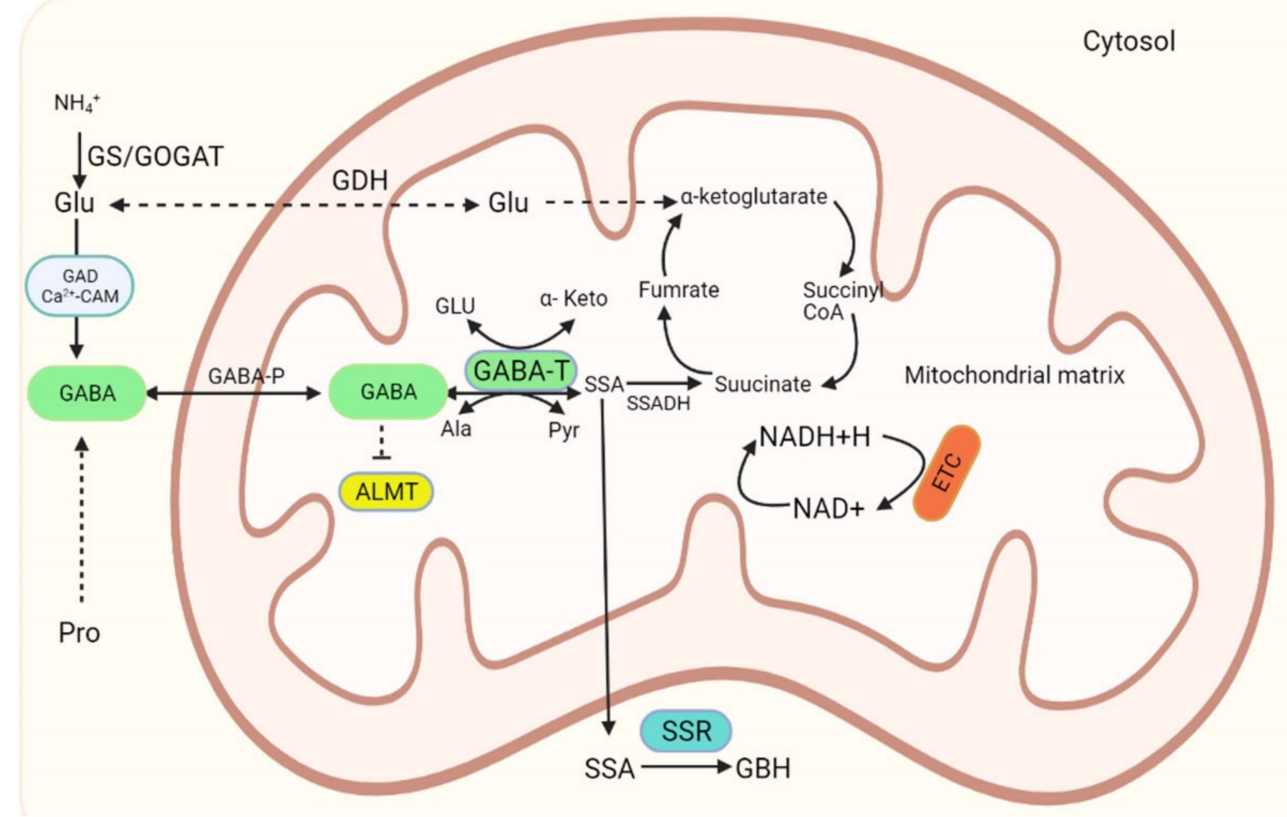

Figure 1. GABA biosynthesis in plants mediated by GABA shunts as adapted from Ramos-Ruiz et al. (2019) [18]. Abbreviations: GAD, glutamate decarboxylase; GABA-P, GABA permease; GABA-T, GABA transaminase; ALMT, aluminum-activated malate transporter; Glu, glutamate; Ala, alanine; Pyr, pyruvate; SSADH, succinic semialdehyde dehydrogenase; ETC, electron transport chain; SSR, succinic semialdehyde reductase; SSA, succinic semialdehyde; GBH, gamma-hydroxybutyric acid.

Pyruvate and glyoxylate are required by GABA-T as amino acceptors and produce alanine and glycine, respectively [19]. In plants, GABA-T prefers 2-oxoglutarate to pyruvate, resulting in glutamate recovery for the GAD response found in plants. Thus, succinate can either enter the TCA cycle as an electron donor in the electron transport chain or be released as succinate from SSADH and enter the TCA cycle [20]. However, SSA can be converted to gamma-hydroxybutyrate (GHB) by GHB dehydrogenase (GHBDH), which also 
occurs in plants, animals, and E. coli [16]. In addition to SSADH, other GABA biosynthesis pathway enzymes in several plant forms have been identified; their numbers vary between different species [21,22]. In plants, it is well-established that GAD contains a calmodulin (CaM)-binding domain, which enables in vitro activity at $\mathrm{pH} 7.0-7.5$ to be activated by the $\mathrm{Ca}^{2+/} \mathrm{CaM}$ complex. At acidic $\mathrm{pH}, \mathrm{GAD}$ activity is influenced by $\mathrm{Ca}^{2+/} \mathrm{CaM}$ and exhibits a distinct $\mathrm{pH}$ optimum at 5.8 [23]. Finally, GABA is synthesized from gamma-amino butyraldehyde, which is produced by the combined activities of 4-aminobutyraldehyde dehydrogenase and diamine oxidase (DAO, E.C. 1.4.3.6) [20].

\section{GABA-Induced Drought Tolerance in Plants}

Drought stress is one of the most serious problems that plants face around the world, negatively affecting their growth and development [24-26]. Overproduction of reactive oxygen species (ROS) causes damage to plant cellular components in drought-stressed plants $[27,28]$. Nevertheless, an increasing amount of evidence shows that stress-induced ROS might have a signaling role [28]. ROS have been found to induce proline synthesis under stress conditions [29,30]. Proline, Ala, Glu, and GABA are all metabolites associated with the GABA shunt that accumulate in plants in response to ROS generation [31-33]. However, it was proposed that certain $\mathrm{ROS}$, such as $\mathrm{H}_{2} \mathrm{O}_{2}$, can activate signal transduction pathways in plant cells [34]. The decrease in NADPH in the nucleus by $\mathrm{H}_{2} \mathrm{O}_{2}$ was proposed as a way to safeguard cell processes against $\mathrm{H}_{2} \mathrm{O}_{2}$-mediated toxicity. For example, $\mathrm{H}_{2} \mathrm{O}_{2}$ reductions in wheat plants are a precondition for the regulation of redox reactions, driving the expression of certain genes throughout the growth of seeds [35]. Furthermore, ROS promote mitochondrial glutamate dehydrogenase (GDH) activity, providing Glu as a precursor for ornithine and GABA production [36] (Figure 2).

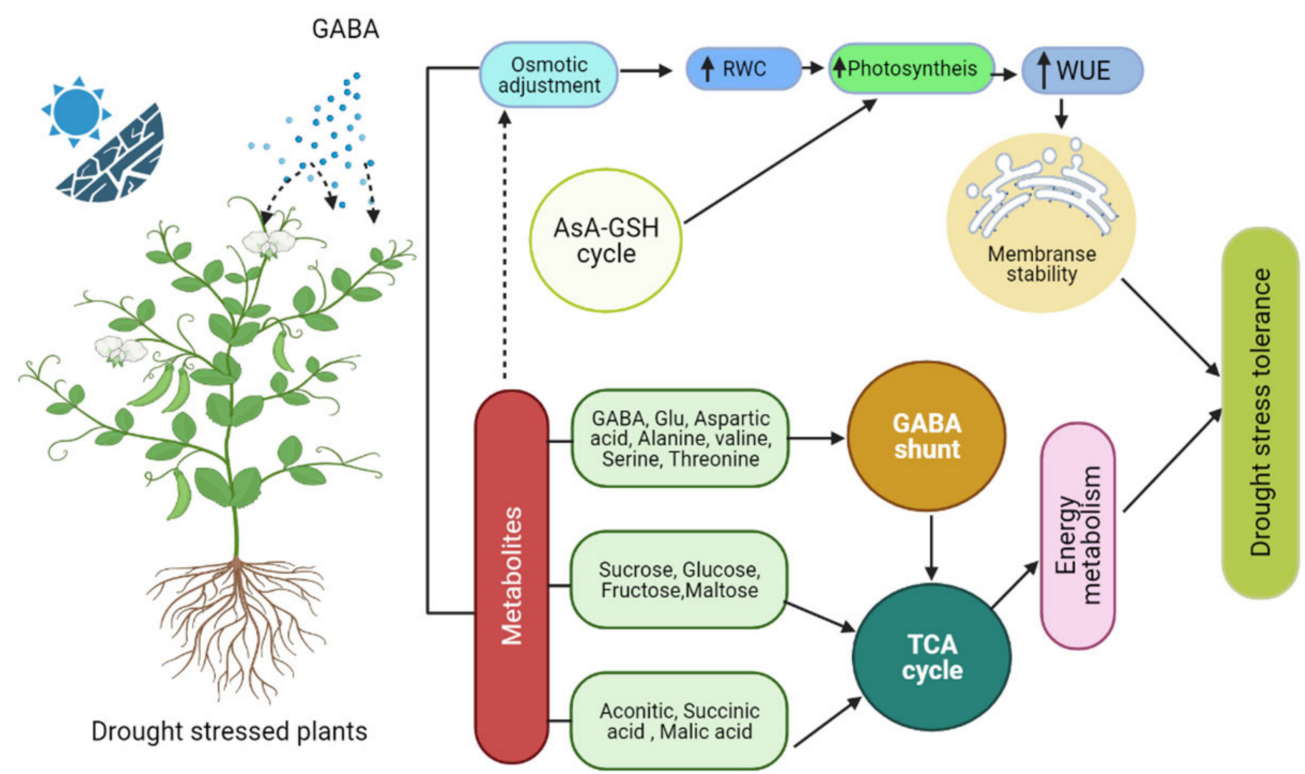

Figure 2. A proposed model demonstrates how GABA protects plants from drought stress.

The protective role of GABA against drought-stress-induced oxidative damage has been demonstrated in a variety of plant species (Figure 2). In Phaseolus vulgaris L., for example, exogenous foliar application of GABA increased fresh shoot weight, dry shoot weight, and leaf area. Through osmotic adjustment, GABA improved drought tolerance in Phaseolus vulgaris L. [37] (Table 1). 
Table 1. GABA-mediated growth, photosynthetic traits, antioxidant defense, and osmoregulation in a wide range of plant species under drought stress.

\begin{tabular}{|c|c|c|c|c|c|}
\hline Species & Stress & GABA Treatment & Effect & Outcome & References \\
\hline $\begin{array}{l}\text { Phaseolus } \\
\text { vulgaris L }\end{array}$ & $\begin{array}{l}\text { Drought (semiarid } \\
\quad \text { conditions) }\end{array}$ & $\begin{array}{l}0.5,1.0 \text { and } \\
2.0 \mathrm{mM} \text { (foliar } \\
\text { application) }\end{array}$ & $\begin{array}{l}\text { Increased leaf area, fresh and dry } \\
\text { shoot weight, } \\
\text { and improved osmotic } \\
\text { adjustment, membrane } \\
\text { permeability, uptake of nutrients, } \\
\text { and antioxidant } \\
\text { defense }\end{array}$ & $\begin{array}{l}\text { Increased drought } \\
\text { tolerance of } \\
\text { Phaseolus } \\
\text { vulgaris L. }\end{array}$ & [37] \\
\hline $\begin{array}{l}\text { Coix } \\
\text { lacryma-jobi } \\
\text { L. }\end{array}$ & Withholding water & $\begin{array}{l}20.0 \mathrm{mM} \text { (foliar } \\
\text { application) }\end{array}$ & $\begin{array}{c}\text { Preserved the electron transport } \\
\text { chain and minimized oxidative } \\
\text { damage caused by reactive } \\
\text { oxygen species }\end{array}$ & $\begin{array}{l}\text { Mitigated the } \\
\text { deleterious effects } \\
\text { of drought in } C \text {. } \\
\text { lacryma-jobi plant } \\
\text { leaves }\end{array}$ & [38] \\
\hline $\begin{array}{l}\text { Ryegrass } \\
\text { (Lolium } \\
\text { perenne) }\end{array}$ & Withholding water & $\begin{array}{c}50.0 \text { or } 70.0 \mathrm{mM} \\
\text { (foliar application) }\end{array}$ & $\begin{array}{l}\text { Reduced lipid peroxidation and } \\
\text { electrolyte leakage and improved } \\
\text { relative water content (RWC) and } \\
\text { antioxidant activity }\end{array}$ & $\begin{array}{l}\text { Alleviated drought } \\
\text { stress in ryegrass } \\
\text { seedlings }\end{array}$ & [39] \\
\hline $\begin{array}{l}\text { Creeping } \\
\text { bentgrass } \\
\text { (Agrostis } \\
\text { stolonifera) }\end{array}$ & $\begin{array}{l}\text { Withholding water } \\
\text { (soil volumetric } \\
\text { water content } \\
\text { declined to } 7 \% \text { ) }\end{array}$ & $\begin{array}{l}0.5 \mathrm{mM} \text { (foliar } \\
\text { application) }\end{array}$ & $\begin{array}{l}\text { Increased turf quality, leaf water } \\
\text { content, cell membrane } \\
\text { permeability, photosynthetic } \\
\text { pigments, and expression of } \\
\text { CDPK26, MAPK1, ABF3, } \\
\text { WRKY75, MYB13, HSP70, MT1, } \\
\text { 14-3-3 }\end{array}$ & $\begin{array}{l}\text { Significantly } \\
\text { improved plant } \\
\text { tolerance to } \\
\text { drought stress }\end{array}$ & [40] \\
\hline $\begin{array}{l}\text { Creeping } \\
\text { bentgrass } \\
\text { (Agrostis } \\
\text { stolonifera) }\end{array}$ & Withholding water & $\begin{array}{l}0.5 \mathrm{mM} \text { (foliar } \\
\text { application) }\end{array}$ & $\begin{array}{l}\text { Increased amino acid (GABA, } \\
\text { glycine, valine, proline, } \\
\text { 5-oxoproline, serine, threonine, } \\
\text { aspartic acid, and glutamic acid) } \\
\text { and organic acid (malic acid, } \\
\text { lactic acid, gluconic acid, malonic } \\
\text { acid, and ribonic acid) } \\
\text { accumulation }\end{array}$ & $\begin{array}{c}\text { Enhanced } \\
\text { drought tolerance }\end{array}$ & [41] \\
\hline $\begin{array}{l}\text { Sunflower } \\
\text { (Helianthus } \\
\text { annuus L.) }\end{array}$ & $\begin{array}{c}50 \% \text { field capacity } \\
\text { of drought stress }\end{array}$ & $\begin{array}{l}2.0 \mathrm{mg} \mathrm{L}^{-1} \text { (foliar } \\
\text { application) }\end{array}$ & $\begin{array}{l}\text { Increased plant height, fresh and } \\
\text { dry weight of shoot and root; } \\
\text { improved osmolyte metabolism, } \\
\text { expression of genes, and } \\
\text { antioxidant enzyme activity }\end{array}$ & $\begin{array}{c}\text { Effectively } \\
\text { alleviated } \\
\text { drought-induced } \\
\text { oxidative stress }\end{array}$ & [10] \\
\hline $\begin{array}{l}\text { Cumin } \\
\text { (Nigella } \\
\text { sativa L.) }\end{array}$ & $\begin{array}{l}\text { Three irrigation } \\
\text { treatments } \\
\text { (irrigation after } 50 \text {, } \\
\text { 100, and } 150 \mathrm{~mm} \\
\text { evaporation based } \\
\text { on evaporation } \\
\text { from class A pan) }\end{array}$ & $\begin{array}{l}0,0.5,1.0, \text { and } 2.0 \\
\mathrm{mg} \mathrm{L}^{-1} \text { (foliar } \\
\text { application) }\end{array}$ & $\begin{array}{l}\text { Significantly improved } \\
\text { chlorophyll content and } \\
\text { antioxidant activity }\end{array}$ & $\begin{array}{l}\text { Improved growth } \\
\text { and productivity }\end{array}$ & [42] \\
\hline $\begin{array}{l}\text { Matricaria } \\
\text { recutita L. }\end{array}$ & $\begin{array}{l}\text { Two levels of } 100 \\
\text { (mild stress) and } \\
150 \text { mm (severe } \\
\text { stress) evaporation } \\
\text { from class A pan }\end{array}$ & $\begin{array}{l}50.0 \mathrm{mM} \text { (foliar } \\
\text { application) }\end{array}$ & $\begin{array}{l}\text { Positive proline response to } \\
\text { severe and mild stress in the } \\
\text { presence of GABA }\end{array}$ & $\begin{array}{l}\text { Improved drought } \\
\text { tolerance }\end{array}$ & [43] \\
\hline
\end{tabular}


Table 1. Cont

\begin{tabular}{|c|c|c|c|c|c|}
\hline Species & Stress & GABA Treatment & Effect & Outcome & References \\
\hline $\begin{array}{c}\text { Black } \\
\text { pepper } \\
\text { (Piper } \\
\text { nigrum L.) }\end{array}$ & $\begin{array}{c}\text { PEG } \\
\text { (polyethylene } \\
\text { glycol } 6000 ; 10 \% \\
w / v \text { ) }\end{array}$ & $\begin{array}{c}2.0 \mathrm{mM} \\
\text { (GABA-primed } \\
\text { black pepper) }\end{array}$ & $\begin{array}{c}\text { Reduced wilting percentage } \\
\text { Increased leaf RWC and } \\
\text { antioxidant enzyme activity; } \\
\text { more rapidly decreased cell } \\
\text { osmotic potential; reduced lipid } \\
\text { peroxidation rate; significantly } \\
\text { decreased inhibition of } \\
\text { photosynthetic and mitochondrial } \\
\text { activity }\end{array}$ & $\begin{array}{l}\text { Enhanced drought } \\
\text { stress tolerance }\end{array}$ & {$[44]$} \\
\hline $\begin{array}{l}\text { White } \\
\text { clover } \\
\text { (Trifolium } \\
\text { repens) }\end{array}$ & $\begin{array}{c}\text { 15\% PEG-induced } \\
\text { drought stress }\end{array}$ & $\begin{array}{c}8.0 \mathrm{mM} \text { (pretreated } \\
\text { plants with GABA } \\
\text { in roots) }\end{array}$ & $\begin{array}{c}\text { Increased activities of GABA } \\
\text { transaminase and alpha ketone } \\
\text { glutarate dehydrogenase; } \\
\text { potential GABA-promoted } \\
\text { production of polyamines (PAs) } \\
\text { and inhibition of their metabolism }\end{array}$ & $\begin{array}{l}\text { Improved drought } \\
\text { tolerance of white } \\
\text { clover }\end{array}$ & [45] \\
\hline
\end{tabular}

Exogenous application of GABA effectively mitigated drought-induced leaf damage in plants, as demonstrated by a considerably increased relative water content and decreased electrolyte leakage and lipid peroxidation [45]. GABA increased drought resistance in plants, as well as the accumulation of amino acids, organic acids, and other osmotic compounds associated with secondary metabolism [41]. Furthermore, exogenous GABA treatment increased GABA transaminase and alpha ketone glutarate dehydrogenase activity in white clover leaves, but glutamate decarboxylase activity was reduced under control and drought conditions, leading to an increase in endogenous glutamate (Glu) and GABA levels [45]. GABA, which acts as a downstream signaling molecule of stress-related transcription factors, such as WRKY, MYB, and bZIP that confer drought tolerance in plants, was shown to increase $\mathrm{Ca}^{2+}$-dependent protein kinase 26 (CDPK26) and mitogen-activated protein kinase 1 (MAPK1) by threefold and fivefold, respectively, during drought stress [40].

\section{GABA and Antioxidant Systems under Drought Stress}

In numerous plant cell organelles, such as plasma membranes, peroxisomes, chloroplasts and mitochondria, reactive oxygen species (ROS) are produced under normal and stressful conditions. The major sources of ROS generation under normal light circumstances are chloroplasts and peroxisomes [46]. ROS overproduction is linked to oxidative damage in plants [47-49] and is regulated by genotype, phase of growth, and conditions such as drought [50]. Plants respond to ROS by increasing antioxidant defenses [51,52], which involves several compounds, such as carotenoids, proline, anthocyanins, ascorbate, tocopherols, flavonols and amino acids, and enzymes, such as superoxide dismutase (SOD), catalase (CAT), peroxidase (POX), ascorbate peroxidase (APX), monodehydroascorbate reductase (MDHAR), and dehydroascorbate reductase (DHAR). In general, cell membrane integrity is protected by antioxidant enzymes when the production of ROS in cells increases under stress. Ascorbate is a ubiquitous non-enzymatic antioxidant with significant potential for not only scavenging reactive oxygen species but also for influencing a number of key processes in plants under both stress and non-stress situations [51,52]. The application of exogenous GABA improved the activities of CAT, POD APX, MDHAR and GR enzymes and reduced $\mathrm{H}_{2} \mathrm{O}_{2}$ production, causing greater tolerance to drought in plants [10]. However, GABA application had no significant influence on the activities of superoxide dismutase and catalase in perennial ryegrass grown under well-watered or drought conditions [39]. These data imply that by activating glyoxalase and antioxidant pathways, GABA increases tolerance to oxidative stress caused by abiotic stressors such as drought. 


\section{GABA-Induced Stomatal Regulations under Drought Stress}

The regulation of the stomatal aperture is a critical driver of plant productivity and drought resilience and has a significant impact on climate due to its influence on global carbon and water cycling $[15,53]$. The stomatal pores are marked by a pair of guard cells. Cell volume and pore aperture are regulated by the fine control of ion and water transport across guard cell membranes via transport proteins in response to opening and closing signals, such as light and dark $[15,49,54]$ (Figure 3).

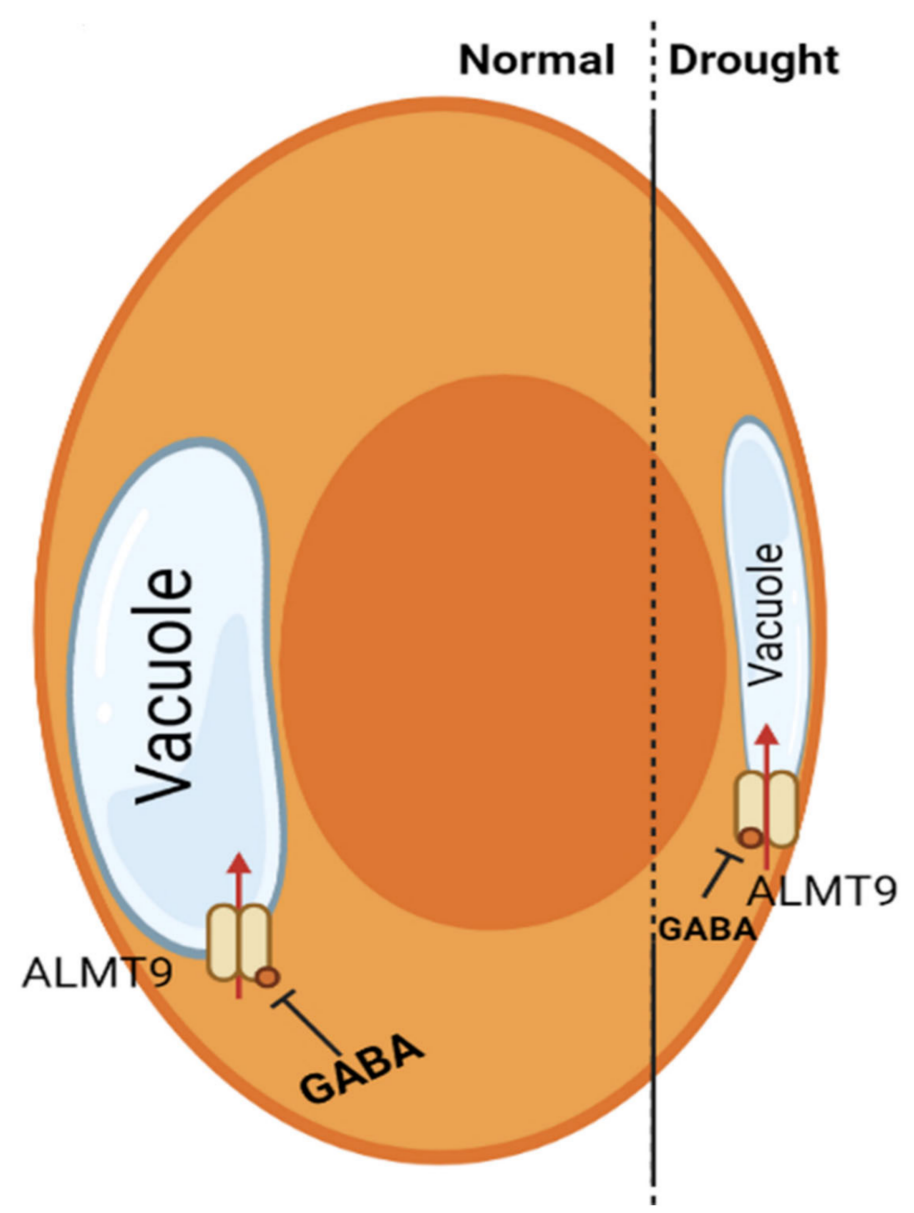

Figure 3. A model for the regulation of water-use efficiency via GABA-mediated signaling adapted from $\mathrm{Xu}$ et al. (2021) [55]. During severe drought, production and storage of leaf GABA decreases ALMT9-mediated vacuolar anion absorption into guard cells, which requires the amino acids F243/Y245 (red dot) (right guard cell of pair). Compared to guard cells under normal conditions in the light, this reduces stomatal opening and pore apertures and increases plant water-use efficiency (WUE) during drought stress (left guard cell of pair).

Stomatal guard cells, due to their essential functions in plant cell signaling and their capacity to respond to and incorporate multiple stimuli, have emerged as a prominent model system for elucidating numerous important pathways that regulate plant biotic and abiotic stress tolerance $[56,57]$. The effects of GABA on stomata have been observed in a variety of plants, including dicot and monocot crops. Recently, GABA and the ALMT1 protein have been discovered to influence plant development through the binding of GABA to the ALTM1 transporter [58,59]. The authors characterized the relationship as typical of ALMT family proteins and speculated that it might alter stomatal movement. ALMT6, ALMT9, and ALMT12 proteins are located in the vacuolar and plasma membranes, and play a role in regulating stomatal movement by enabling malate influx and efflux $[60,61]$. Meyer et al. (2011) [62] suggested the existence of a cofactor (cytosolic or vacuolar) that binds 
to and controls the action of the ALMT6 protein since removing $\mathrm{Ca}^{2+}$ from the activated protein had no effect on activity. In recent years, Xu et al. 2021 [55] revealed a GABA signaling route in plants, which is described by the simplified models provided in Figure 3. This work suggested that cytosolic GABA signals generated by GAD2 affect stomatal opening, water-use efficiency (WUE), and drought tolerance by negatively controlling the activity of ALMT9. ALMT9 is a key component for the transduction of GABA signals in cells under well-watered and drought conditions (Figure 3). However, the effect of GABA on stomatal closure under drought is still not clear. In addition, preceding research concluded that GABA regulation of stomata might be caused by light, dark, and low signal intermediate concentrations.

\section{GABA and Polyamines Interrelationships under Drought Stress}

Polyamines (PAs) are found in most eukaryotic cells and mainly include Put, Spd, and Spm, which are classified as free, conjugated, or bound in higher plants [63]. Under stressed conditions, other plants display an increase in PA biosynthesis and catabolism $[63,64]$. PA is widely used in living organisms [65] and is projected to be a signaling molecule that plays pivotal roles throughout physiological processes in regulating developmental stages, such as embryonic differentiation [66], cell death responses [67], fruit ripening [68], and seed germination [69]. PA biosynthesis is caused by ornithine or arginine decarboxylation, which is mediated by the decarboxylase (ORD) of ornithine or the decarboxylase of arginine, respectively (Figure 4).

The importance of GABA in plant tolerance and its relationship with PAs have been thoroughly documented [63]. PA catabolism generates GABA through $\mathrm{CuAO}$ or PAO catalysis, which is a direct link between GABA and PAs. Yang et al. (2013) [70] showed that under hypoxic stress, PA degradation provided approximately $30 \%$ of the GABA content in fava beans (Vicia faba). Three enzymes (ADC, ODC, and SMADC) involved in the production of Pas, and two enzymes (CuAO and PAO) involved in the breakdown of Pas, were activated under drought conditions [45]. The findings showed GABA boosted PA synthesis but, at the same time, inhibited PA catabolism, which increased the overall PA content in GABA-treated plants grown under drought. This result showed that enhanced endogenous GABA acted as negative feedback for the breakdown of PAs, which was in accordance with the findings of Wang et al. (2014) [64].

PA accumulation in various plants was observed under environmental stresses, and the critical roles of PA were validated in plants [13]. Similarly, the accumulation of GABA was reported to reduce the oxidative damage produced by ROS, resulting in increased oxidative stress tolerance [71]. In soybean plants, drought stress led to the accumulation of GABA. This was accomplished by boosting the activity of diamine oxidase (DAO) to increase PA breakdown, which suggests that PA regulates GABA accumulation-driven tolerance responses [72]. In addition, muskmelon (Cucumis melo) exposed to salt stress exhibited degradation and endogenous GABA accumulation [73]. Following exogenous GABA treatment, the accumulation of Put, Spm, and Spd was documented by blocking PA degradation (Figure 4). These results indicated that GABA might act as an additional modulator of plant tolerance by modulating the metabolism of PAs. Under conditions of stress, GABA boosts PA levels by blocking its own synthesis. However, the exact mechanism through which this regulatory system is induced in plants remains unknown. 


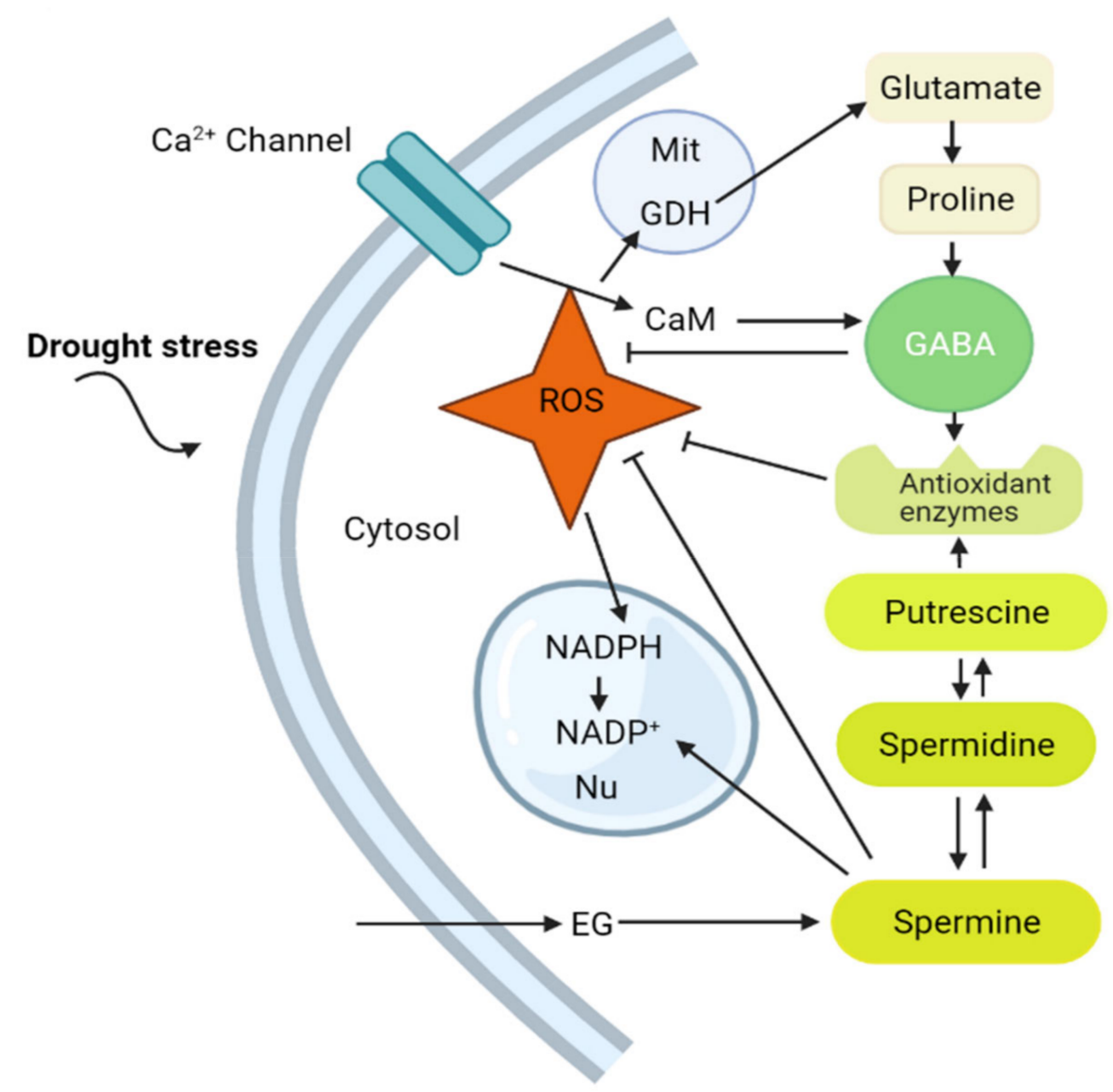

Figure 4. The interrelationship between GABA and PAs mediating ROS in plants. ROS stimulate the activity of GDH in the mitochondria, resulting in the synthesis of Glu, a precursor to GABA. GABA accumulates in response to drought stress via CaM protein-mediated activation of the GAD enzyme and $\mathrm{Ca}^{2+}$ signaling. When drought stress occurs, PA biosynthesis increases, which results in GABA biosynthesis. GABA and PAs boost antioxidant enzyme (AE) activity, impairing the synthesis and function of ROS in plant cells. Abbreviations: $\mathrm{Ca}^{2+}$, calcium; $\mathrm{CaM}$, calmodulin protein; ROS, reactive oxygen species; GDH, glutamate dehydrogenase; Mit, mitochondria; NADP, nicotinamide adenine dinucleotide phosphate; Nu, nucleus; EG, exogenous GABA.

\section{Conclusions and Future Perspective}

In plants, GABA plays a key role in the control of abiotic stress tolerance. GABA use in stressed plants enhances the activities of the GABA shunt; boosts the photosynthetic efficiency of endogenous GABA and antioxidative enzymes; reduces ROS production, MDA, and $\mathrm{H}_{2} \mathrm{O}_{2}$ content; and protects the cell membrane. The majority of studies were conducted under abiotic stress; hence, the significance of the GABA shunt and its metabolites remains unclear, which requires further investigation. GABA plays a major role in the movement of the stomata in plants, especially under drought stress. We think that GABA may have a significant function in the closure and opening of stomata in plants. Substantial work has elucidated the overall function of GABA-mediated stomatal control under drought stress, but more research is needed to clarify the processes behind that control and how it interacts with other elements of stomatal function.

Finally, it is proposed that GABA plays a positive role in physiological regulation when plants are exposed to adverse environmental pressures; thus, manipulating GABA levels could be a viable technique for improving plant stress resistance. This detailed analysis of the synthesis and stress-mitigating role of GABA could be used to increase 
the amount and quality of agricultural products and contribute to the achievement of sustainable development goals.

Author Contributions: Conceptualization, comprehensive writing, reviewing, figure generation, and manuscript preparation, M.M.H.; writing and review, M.M.H., N.M.A., B.M.A., M.W., G.Y., X.-D.L., X.-W.F. and M.S.J.; writing, review, and figure generation, M.M.H., H.G.A.E.-G., B.M.A., A.A.E.-Y., M.F.M.I. and X.-W.F.; funding acquisition X.-W.F. All authors have read and agreed to the published version of the manuscript.

Funding: The research was supported by the National Natural Science Foundation of China (Nos. 31971406, and 31670404), and the Fundamental Research Funds for the Central Universities (lzujbky2021-pd07).

Institutional Review Board Statement: Not applicable.

Informed Consent Statement: Not applicable.

Data Availability Statement: Not applicable.

Acknowledgments: The authors would like to extend their sincere appreciation to the State Key Laboratory of Grassland Agroecosystems, School of Life Sciences, Lanzhou University, China.

Conflicts of Interest: The authors declare no conflict of interest among them.

\section{References}

1. Steward, F.C. $\gamma$-Aminobutyric acid: A constituent of the potato tuber? Science 1949, 110, 439-440.

2. Li, L.; Dou, N.; Zhang, H.; Wu, C. The versatile GABA in plants. Plant Signal Behav. 2021, 16, 3. [CrossRef] [PubMed]

3. Roberts, M.R. Does GABA act as a signal in plants? Hints from molecular studies: Hints from molecular studies. Plant Signal. Behav. 2007, 2, 408-409. [CrossRef] [PubMed]

4. Jaleel, C.A.; Manivannan, P.; Whid, A.; Farooq, M.; Al-Juburi, H.J.; Somasundaram, R.; Panneerselvam, R. Drought stress in plants: A review on morphological characteristics and pigments composition. Int. J. Agric. Biol. 2009, 11, 100-105.

5. Farooq, M.; Wahid, A.; Kobayashi, N.; Fujita, D.; Basra, S.M.A. Plant drought stress: Effects, mechanisms and management. Agron. Sustain. Agric. 2009, 29, 153-188.

6. Vanani, F.R.; Shabani, L.; Sabzalian, M.R.; Dehghanian, F.; Winner, L. Comparative physiological and proteomic analysis indicates lower shock response to drought stress conditions in a self-pollinating perennial ryegrass. PLoS ONE 2020, 15, e0234317.

7. Yao, G.Q.; Li, F.P.; Nie, Z.F.; Bi, M.H.; Jiang, H.; Liu, X.D.; Wei, Y.; Fang, X.W. Ethylene, not ABA, is closely linked to the recovery of gas exchange after drought in four Caragana species. Plant Cell Environ. 2020, 44, 399-411. [CrossRef] [PubMed]

8. Li, Z.; Yu, J.; Peng, Y.; Huang, B. Metabolic pathways regulated by abscisic acid, salicylic acid, and $\gamma$-aminobutyric acid in association with improved drought tolerance in creeping bentgrass (Agrostis stolonifera). Physiol. Plant. 2017, 159, 42-58. [CrossRef]

9. Nahar, K.; Rahman, M.; Hasanuzzaman, M.; Alam, M.M.; Rahman, A.; Suzuki, T.; Fujita, M. Physiological and biochemical mechanisms of spermine-induced cadmium stress tolerance in mung bean (Vigna radiata L.) seedlings. Environ. Sci. Pollut. Res. 2016, 23, 21206-21218. [CrossRef] [PubMed]

10. Razik, E.S.A.; Alharbi, B.M.; Pirzadah, T.B.; Alnusairi, G.S.H.; Soliman, M.H.; Hakeem, K.R. $\gamma$-Aminobutyric acid (GABA) mitigates drought and heat stress in sunflower (Helianthus annuus L.) by regulating its physiological, biochemical and molecular pathways. Physiol. Plant. 2020, 172, 505-527. [CrossRef]

11. Hasan, M.M.; Gong, L.; Nie, Z.; Feng, X.; Ahammed, G.J.; Fang., X.W. ABA-induced stomatal movements in vascular plants during dehydration versus rehydration. Environ. Exp. Bot. 2021, 186, 104436. [CrossRef]

12. Hasan, M.M.; Rahman, M.A.; Skalicky, M.; Alabdallah, N.M.; Waseem, M.; Jahan, M.S.; Ahammed, G.J.; El-Mogy, M.M.; El-Yazied, A.A.; Ibrahim, M.F.M.; et al. Ozone Induced Stomatal Regulations, MAPK and Phytohormone Signaling in Plants. Int. J. Mol. Sci. 2021, 22, 6304. [CrossRef]

13. Yang, Y.J.; Bi, M.H.; Nie, Z.F.; Jiang, H.; Liu, X.D.; Fang, X.W.; Brodribb, T.J. Evolution of stomatal closure to optimise water use efficiency in response to dehydration in ferns and seed plants. New Phytol. 2021, 230, 2001-2010. [CrossRef]

14. Gong, L.; Liu, X.D.; Zeng, Y.Y.; Tian, X.Q.; Li, Y.L.; Turner, N.C.; Fang, X.W. Differences in stomatal morphology and physiology explain differences in stomatal sensitivity to abscisic acid across vascular plant lineages. Plant Physiol. 2021, 186, 782-797. [CrossRef] [PubMed]

15. Papanatsiou, M.; Petersen, J.; Henderson, L.; Wang, Y.; Christie, J.M.; Blatt, M.R. Optogenetic manipulation of stomatal kinetics improves carbon assimilation, water use, and growth. Science 2019, 363, 1456-1459. [CrossRef] [PubMed]

16. Rashmi, D.; Zanan, R.; John, S.; Khandagale, K.; Nadaf, A. $\gamma$-aminobutyric acid (GABA): Biosynthesis, role, commercial production, and applications. Stud. Nat. Prod. Chem. 2018, 57, 413-452.

17. Bown, A.W.; Shelp, B.J. The metabolism and functions of [gamma]-aminobutyric acid. Plant Physiol. 1997, 115, 1-15. [CrossRef]

18. Ramos-Ruiz, R.; Martinez, F.; Knauf-Beiter, G. The effects of GABA in plants. Cogent Food Agric. 2019, 5, 1670553. [CrossRef] 
19. Clark, S.M.; Di Leo, R.; Dhanoa, P.K.; Van Cauwenberghe, O.R.; Mullen, R.T.; Shelp, B.J. Biochemical characterization, mitochondrial localization, expression, and potential functions for an Arabidopsis c-aminobutyrate transaminase that utilizes both pyruvate and glyoxylate. J. Exp. Bot. 2009, 60, 1743-1757. [CrossRef]

20. Akihiro, T.; Koike, S.; Tani, R.; Tominaga, T.; Watanabe, S.; Iijima, Y.; Aoki, K.; Shibata, D.; Ashihara, H.; Matsukura, C.; et al. Biochemical mechanism on GABA accumulation during fruit development in tomato. Plant Cell Physiol. 2008, 49, 1378-1389. [CrossRef] [PubMed]

21. Shelp, B.J.; Mullen, R.T.; Waller, J.C. Compartmentation of GABA metabolism raises intriguing questions. Trends Plant Sci. 2012, 17, 57-59. [CrossRef] [PubMed]

22. Trobacher, C.P.; Clark, S.M.; Bozzo, G.G.; Mullen, R.T.; DeEll, J.; Shelp, B.J. Catabolism of GABA in apple fruit: Subcellular localization and biochemical characterization of two c-aminobutyrate transaminases. Postharvest Biol. Tech. 2013, 75, 106-113. [CrossRef]

23. Priya, M.; Sharma, L.; Kaur, R.; Bindumadhava, H.; Nair, R.M.; Siddique, K.H.M.; Nayyar, H. GABA ( $\gamma$-aminobutyric acid), as a thermo-protectant, to improve the reproductive function of heat-stressed mungbean plants. Sci. Rep. 2019, 9, 7788. [CrossRef] [PubMed]

24. Jahan, M.S.; Wang, Y.; Shu, S.; Hasan, M.M.; El-Yazied, A.A.; Alabdallah, N.M.; Hajjar, D.; Altaf, M.A.; Sun, J.S.; Guo, S. Melatonin pretreatment confers heat tolerance and repression of heat-induced senescence in tomato through the modulation of ABA and GA-mediated pathways. Front. Plant Sci. 2021, 12, 650955. [CrossRef] [PubMed]

25. Waseem, M.; Nie, N.F.; Yao, G.Q.; Hasan, M.M.; Xiang, Y.; Fang, X.W. Dew absorption by leaf trichomes in Caragana korshinskii: An alternative water acquisition strategy to withstand drought in arid environment. Physiol. Plant. 2021, 172, 528-539. [CrossRef]

26. Hasan, M.M.; Alharby, H.F.; Hajar, A.S.; Hakeem, K.R.; Alzahrani, Y. The effect of magnetized water on the growth and physiological conditions of Moringa species under drought stress. Pol. J. Environ. Stud. 2019, 28, 1145-1155. [CrossRef]

27. Hasan, M.M.; Ali, M.A.; Soliman, M.H.; Alqarawi, A.A.; Abd Allah, E.F.; Fang, X.W. Insights into 28-homobrassinolide (HBR)Mediated redox homeostasis, AsA-GSH cycle, and methylglyoxal detoxification in soybean under drought-induced oxidative stress. J. Plant Inter. 2020, 15, 371-385. [CrossRef]

28. Hasan, M.M.; Alharby, H.F.; Uddin, M.N.; Ali, M.A.; Anwar, Y.; Fang, X.W.; Hakeem, K.R.; Alzahrani, Y.; Hajar, A.S. Magnetized water confers drought stress tolerance in Moringa biotype via modulation of growth, gas exchange, lipid peroxidation and antioxidant activity. Pol. J. Environ. Stud. 2020, 29, 1625-1636. [CrossRef]

29. Hasan, M.M.; Hajar, A.S.; Alharby, H.F.; Hakeem, K.R. Effects of magnetized water on phenolic compounds, lipid peroxidation and antioxidant activity of Moringa species under drought stress. J. Anim. Plant Sci. 2018, 28, 803-810.

30. Khan, A.; Anwar, Y.; Hasan, M.; Iqbal, A.; Ali, M.; Alharby, H.F.; Hakeem, K.R.; Hasanuzzaman, M. Attenuation of drought stress in Brassica seedlings with exogenous application of $\mathrm{Ca}^{2+}$ and $\mathrm{H}_{2} \mathrm{O}_{2}$. Plants 2017, 6, 20. [CrossRef]

31. Zhang, L.; Becker, D.F. Connecting proline metabolism and signaling pathways in plant senescence. Front. Plant Sci. 2015,6 , 552. [CrossRef] [PubMed]

32. Suzuki, N.; Mittler, R. Reactive oxygen species and temperature stresses: A delicate balance between signaling and destruction. Physiol. Plant. 2006, 126, 45-51. [CrossRef]

33. Bouche, N.; Fromm, H. GABA in plants: Just a metabolite? Trends Plant Sci. 2004, 9, 110-115. [CrossRef] [PubMed]

34. Tripathy, B.C.; Oelmüller, R. Reactive oxygen species generation and signaling in plants. Plant Signal. Behav. 2012, 7, 1621-1633. [CrossRef] [PubMed]

35. Pulido, P.; Domínguez, F.; Cejudo, F.J. A hydrogen peroxide detoxification system in the nucleus of wheat seed cells: Protection or signaling role? Plant Signal. Behav. 2009, 4, 23-25. [CrossRef]

36. Skopelitis, D.S.; Paranychianakis, N.V.; Paschalidis, K.A.; Pliakonis, E.D.; Delis, I.D.; Yakoumakis, D.I.; Kouvarakis, A.; Papadakis, A.K.; Stephanou, E.G.; Roubelakis-Angelakis, K.A. Abiotic stress generates ROS that signal expression of anionic glutamate dehydrogenases to form glutamate for proline synthesis in tobacco and grapevine. Plant Cell 2006, 18, 2767-2781. [CrossRef]

37. Abd El-Gawad, H.G.; Mukherjee, S.; Farag, R.; Abd Elbar, O.H.; Hikal, M.; Abou El-Yazied, A.; Abd Elhady, S.A.; Helal, N.; ElKelish, A.; El Nahhas, N.; et al. Exogenous $\gamma$-aminobutyric acid (GABA)-induced signaling events and field performance associated with mitigation of drought stress in Phaseolus vulgaris L. Plant Signal. Behav. 2020, 16, 1853384. [CrossRef]

38. Ferreira, R.A.; Borella, J.; Hüther, C.M.; do Canto, A.C.B.; da Costa Correa, N.P.; Correia, D.M.; Borges, R.P.; de Pinho, C.F.; Machado, T.B.; Pereira, C.R. Drought induced stress in leaves of Coix lacryma-jobi L. under exogenous application of proline and GABA amino acids. Braz. J. Bot. 2020, 43, 513-521. [CrossRef]

39. Krishnan, S.; Laskowski, K.; Shukla, V.; Merewitz, E.B. Mitigation of Drought Stress Damage by Exogenous Application of a Non-Protein Amino Acid $\gamma$-Aminobutyric Acid on Perennial Ryegrass. J. Am. Soc. Hort. Sci. 2013, 138, 358-366. [CrossRef]

40. Li, Z.; Peng, Y.; Huang, B. Alteration of Transcripts of Stress-Protective Genes and Transcriptional Factors by $\gamma$-Aminobutyric Acid (GABA) Associated with Improved Heat and Drought Tolerance in Creeping Bentgrass (Agrostis stolonifera). Int. J. Mol. Sci. 2018, 19, 1623. [CrossRef]

41. Li, Z.; Yu, J.; Peng, Y.; Huang, B. Metabolic pathways regulated by $\gamma$-aminobutyric acid (GABA) contributing to heat tolerance in creeping bentgrass (Agrostis stolonifera). Sci. Rep. 2016, 6, 30338. [CrossRef]

42. Rezaei-Chiyaneh, E.; Seyyedi, S.M.; Ebrahimian, E.; Moghaddam, S.S.; Damalas, C.A. Exogenous application of gammaaminobutyric acid (GABA) alleviates the effect of water deficit stress in black cumin (Nigella sativa L.). Ind. Crops Prod. 2018, 112, 741-748. [CrossRef] 
43. Sadaghiani, F.M.; Dehaghi, M.A.; Pirzad, A.; Fotokian, M.H. Variation in yield and biochemical factors of German chamomile (Matricaria recutita L.) under foliar application of osmolytes and drought stress conditions. J. Herbmed Pharmacol. 2019, 8, 90-100. [CrossRef]

44. Vijayakumari, K.; Puthur, J.T. $\gamma$-Aminobutyric acid (GABA) priming enhances the osmotic stress tolerance in Piper nigrum Linn. plants subjected to PEG-induced stress. Plant Growth Regul. 2016, 78, 57-67. [CrossRef]

45. Yong, B.; Xie, H.; Li, Z.; Li, Y.P.; Zhang, Y.; Nie, G.; Zhang, X.Q.; Ma, X.; Huang, L.K.; Yan, Y.H.; et al. Exogenous application of GABA improves PEG-induced drought tolerance positively associated with GABA-shunt, polyamines, and proline metabolism in white clover. Front. Physiol. 2017, 8, 1107. [CrossRef]

46. Gill, S.S.; Tuteja, N. Reactive oxygen species and antioxidant machinery in abiotic stress tolerance in crop plants. Plant Physiol. Biochem. 2010, 48, 909-930. [CrossRef]

47. Alharbi, B.M.; Elhakem, A.H.; Alnusairi, G.S.H.; Mona, H.; Soliman, M.H.; Hakeem, K.R.; Hasan, M.M.; Abdelhamid, M.T. Exogenous application of melatonin alleviates salt stress-induced decline in growth and photosynthesis in Glycine max (L.) seedlings by improving mineral uptake, antioxidant and glyoxalase system. Plant Soil Environ. 2021, 67, 208-220. [CrossRef]

48. Guler, N.S.; Pehlivan, N. Exogenous low-dose hydrogen peroxide enhances drought tolerance of soybean (Glycine max L.) through inducing antioxidant system. Acta Biol. Hung. 2016, 67, 169-183. [CrossRef]

49. Hasan, M.M.; Skalicky, M.; Jahan, M.S.; Hossain, M.N.; Anwar, Z.; Nie, Z.F.; Alabdallah, N.M.; Brestic, M.; Hejnak, V.; Fang, X.-W. Spermine: Its Emerging Role in Regulating Drought Stress Responses in Plants. Cells 2021, 10, 261. [CrossRef]

50. Abedi, T.; Pakniyat, H. Antioxidant enzyme changes in response to drought stress in ten cultivars of oilseed rape (Brassica napus). Czech J. Genet. Plant Breed. 2010, 46, 27-34. [CrossRef]

51. Slabbert, M.M.; Krüger, G.H.J. Antioxidant enzyme activity, proline accumulation, leaf area and cell membrane stability in water stressed Amaranthus leaves. S. Afr. J. Bot. 2014, 95, 123-128. [CrossRef]

52. Capell, T.; Bassie, L.; Christou, P. Modulation of the polyamine biosynthetic pathway in transgenic rice confers tolerance to drought stress. Proc. Natl. Acad. Sci. USA 2004, 101, 9909-9914. [CrossRef]

53. Keenan, T.F.; Hollinger, D.Y.; Bohrer, G.; Dragoni, D.; Munger, J.W.; Schmid, H.P.; Richardson, A.D. Increase in forest water-use efficiency as atmospheric carbon dioxide concentrations rise. Nature 2013, 499, 324-327. [CrossRef] [PubMed]

54. Sussmilch, F.C.; Schultz, J.; Hedrich, R.; Roelfsema, M.R.G. Acquiring control: The evolution of stomatal signalling pathways. Trends Plant Sci. 2019, 24, 342-351. [CrossRef]

55. Xu, B.; Long, Y.; Feng, X.; Zhu, X.; Sai, N.; Chirkova, L.; Betts, A.; Herrmann, J.; Edwards, E.J.; Okamoto, M.; et al. GABA signalling modulates stomatal opening to enhance plant water use efficiency and drought resilience. Nat. Commun. 2021, 12, 1952. [CrossRef]

56. Yao, G.Q.; Nie, Z.F.; Turner, N.C.; Li, F.M.; Gao, T.P.; Fang, X.W.; Scoffoni, C. Combined high leaf hydraulic safety and efficiency provides drought tolerance in Caragana species adapted to low mean annual precipitation. New Phytol. 2021, 229, 230-244. [CrossRef] [PubMed]

57. Murata, Y.; Mori, I.C.; Munemasa, S. Diverse stomatal signaling and the signal integration mechanism. Annu. Rev. Plant Biol. 2015, 66, 369-392. [CrossRef] [PubMed]

58. Renault, H.; El Amrani, A.; Palanivelu, R.; Updegraff, E.P.; Yu, A.; Renou, J.P.; Preuss, D.; Bouchereau, A.; Deleu, C. GABA accumulation causes cell elongation defects and a decrease in expression of genes encoding secreted and cell wall-related proteins in Arabidopsis thaliana. Plant Cell Physiol. 2011, 52, 894-908. [CrossRef]

59. Ramesh, S.A.; Tyerman, S.D.; Xu, B.; Bose, J.; Kaur, S.; Conn, V.; Domingos, P.; Ullah, S.; Wege, S.; Shabala, S.; et al. GABA signaling modulates plant growth by directly regulating the activity of plant-specification transporters. Nat. Commun. 2015, 6, 7879. [CrossRef]

60. Meyer, S.; Mumm, P.; Imes, D.; Endler, A.; Weder, B.; Al-Rasheid, K.A.; Geiger, D.; Marten, I.; Martinoia, E.; Hedrich, R. AtALMT12 represents an R-type anion channel required for stomata movement in Arabidopsis guard cells. Plant J. 2010, 63, 1054-1062. [CrossRef]

61. Mekonnen, D.W.; Flügge, U.I.; Ludewig, F. Gamma-aminobutyric acid depletion affects stomata closure and drought tolerance of Arabidopsis thaliana. Plant Sci. 2016, 245, 25-34. [CrossRef]

62. Meyer, S.; Scholz-Starke, J.; De Angeli, A.; Kovermann, P.; Burla, B.; Gambale, F.; Martinoia, E. Malate transport by the vacuolar AtALMT6 channel in guard cells is subject to multiple regulation. Plant J. 2011, 67, 247-257. [CrossRef]

63. Hu, X.; Xu, Z.; Xu, W.; Li, J.; Zhao, N.; Zhou, Y. Application of $\gamma$-aminobutyric acid demonstrates a protective role of polyamine and GABA metabolism in muskmelon seedlings under $\mathrm{Ca}\left(\mathrm{NO}_{3}\right)_{2}$. Plant Physiol. Biochem. 2015, 92, 1-10. [CrossRef] [PubMed]

64. Wang, C.; Fan, L.; Gao, H.; Wu, X.; Li, J.; Lv, G.; Gong, B. Polyamine biosynthesis and degradation are modulated by exogenous gamma-aminobutyric acid in root-zone hypoxia-stressed melon roots. Plant Physiol. Biochem. 2014, 82, 17-26. [CrossRef] [PubMed]

65. Mattoo, A.K.; Minocha, S.C.; Minocha, R.; Handa, A.K. Polyamines and cellular metabolism in plants: Transgenic approaches reveal different responses to diamine putrescine versus higher polyamines spermidine and spermine. Amino Acids 2010, 38, 405-413. [CrossRef]

66. Silveira, V.; de Vita, A.M.; Macedo, A.F.; Dias, M.F.R.; Floh, E.I.S.; Santa-Catarina, C. Morphological and polyamine content changes in embryogenic and non-embryogenic callus of sugarcane. Plant Cell Tissue Organ Cult. 2013, 114, 351-364. [CrossRef] 
67. Kim, N.H.; Kim, B.S.; Hwang, B.K. Pepper arginine decarboxylase is required for polyamine and $\gamma$-aminobutyric acid signaling in cell death and defense response. Plant Physiol. 2013, 162, 2067-2083. [CrossRef]

68. Gil-Amado, J.A.; Gomez-Jimenez, M.C. Regulation of polyamine metabolism and biosynthetic gene expression during olive mature-fruit abscission. Planta 2012, 235, 1221-1237. [CrossRef]

69. Fait, A.; Fromm, H.; Walter, D.; Galili, G.; Fernie, A.R. Highway or byway: The metabolic role of the GABA shunt in plants. Trends Plant Sci. 2008, 13, 14-19. [CrossRef] [PubMed]

70. Yang, R.; Guo, Q.; Gu, Z. GABA shunt and polyamine degradation pathway on $\gamma$-aminobutyric acid accumulation in germinating fava bean (Vicia faba L.) under hypoxia. Food Chem. 2013, 136, 152-159. [CrossRef]

71. AL-Quraan, N.A. GABA shunt deficiencies and accumulation of reactive oxygen species under UV treatments: Insight from Arabidopsis thaliana calmodulin mutants. Acta Physiol. Plant. 2015, 37, 86. [CrossRef]

72. Xing, S.G.; Jun, Y.B.; Hau, Z.W.; Liang, L.Y. Higher accumulation of $\gamma$-aminobutyric acid induced by salt stress through stimulating the activity of diamine oxidases in Glycine max (L.) Merr. roots. Plant Physiol. Biochem. 2007, 45, 560-566. [CrossRef] [PubMed]

73. Xiang, L.; Hu, L.; Xu, W.; Zhen, A.; Zhang, L.; Hu, X. Exogenous $\gamma$-aminobutyric acid improves the structure and function of photosystem II in muskmelon seedlings exposed to salinity-alkalinity stress. PLoS ONE 2016, 11, e0164847. [CrossRef] [PubMed] 